\title{
ANALYSES OF IMPELLER TYPE WIND TURBINE
}

\author{
A.Y. QASIM, R. USUBAMATOV AND Z.M. ZAIN \\ School of Manufacturing Engineering, University Malaysia Perlis, \\ Ulu Pauh, Arau, 02600 Perlis, Malaysia. \\ ayhk66@yahoo.com,ryspek@unimap.edu.my,zuraidah@unimap.edu.my
}

\begin{abstract}
The new globaldevelopment for wind turbines obliged inventors to create new wind turbine designs that have high efficiency and better than known designs. This paper proposes the impeller wind turbine, which uses more effectively the wind energy and depends only on the acting area of the vanes. The vane wind turbine is designed to increase the drag coefficient and output of a wind turbine that uses kinetic energy of the wind. Itcan be used worldwide due to its high efficiency, simple construction, and simple technology and can be made from cheap materials.
\end{abstract}

ABSTRAK: Pembangunan global terkini turbin angin menyebabkan pereka harus membina rekaan terbaru turbin angin yang bercekapan tinggi yang lebih baik daripada rekaan-rekaan terdahulu. Kertas ini mencadangkan pendesak turbin angin, yang menggunakan kuasa angin secara lebih efektif dan bergantung hanya terhadap permukaan bilah kipas yang terlibat. Bilah kipas turbin angin direka sebegini untuk meningkatkan pekali seret dan juga keluaran daripada turbin angin tersebut yang menggunakan tenaga kinetik angin. Cara ini boleh digunakan secara meluas di serata dunia kerana ia bercekapan tinggi, mudah dibina, menggunakan teknologi yang ringkas dan diperbuat daripada bahan-bahan yang murah.

KEYWORDS: wind turbine; vane; design; energy

\section{INTRODUCTION}

Wind power is the conversion of wind kinetic energy into a useful form, such as mechanical or electrical energy that can be harnessed for practical use by using wind turbines. Wind turbine technology has steadily improved $[1,2]$. Various wind turbine mechanisms are proposed and built for capturing and converting the kinetic energy of winds. The wind turbineuse mainly aerodynamic lift force and drag forces acting on the surfaces of blades or vanes. In area of the wind energy there are two main type of wind turbine, the horizontal axial and the vertical axial (Darrieus and Savonius turbines), and there are many variants of each design as well, as a number of other similar devices under development. The wind screw turbine is most commonly used in large-scale applications constituting nearly all of the turbines in the global market, while the vertical axis turbines are more commonly implemented in medium and small-scale installations. The technical characteristics of wind turbines are to be found elsewhere [3-5]. However, simple analysis of these wind turbine designs shows that these designs are not perfect, the wind force does not use in full-scale due to many technical reasons.

A wind screw turbine designed mainly of three blades and use the aerodynamic lift force. The wind passes freely between blades and does not affect on output of turbine. The real 
output the power of the wind screw turbine is 4-5 times less than theoretical power one. The work of the Darrieus-type turbine based also on the aerodynamic lift force, but its power output is small. The work of the Savonius-type turbine based on the differences of drag forces, but its power output is small. These two turbines cannot be installed on high altitude due to many engineering limitations.

Hence, there is necessity to design new type of the wind turbines without mentioned above lacks and with ability of use in wide area of application. Designing a wind turbine system that can generate power with high efficiency requires a thorough understanding of the principles of aerodynamics and structural dynamics of the rotor system. First, new design should use the wind kinetic energy by maximum of the Betz limit [1].

Researchers state that wind turbines of lift force design theoretically have higher power efficiencies than turbines of drag force design. Other research states that at conditions of turbulent with rapid changes in wind direction practically more power will be generated by turbines of drag force design, despite its lower efficiency [2]. However, there is the following vital information: the power output of a wind generator is proportional to the acting area of wind turbines and the power output of a wind generator is proportional to the cube of the wind speed. These peculiarities should be considered as main factors of the output power to design new type of wind turbines.

Hence, capturing and converting the kinetic energy of winds depends on the active area of the blades, vanes or other elements of the wind turbines and on the wind speed, which increases with altitude of the turbine location regarding the earth level.

\section{BRIEF DESCRIPTION OF THE DESIGN AND WORK OF THE IMPELLER TYPE WIND TURBINE}

Problems of the wind turbine presented above can be solved by new design of the vertical axis impeller type wind turbine with movable vanes. New turbinehas simple construction, technologically simple in production, anduses the drag force by active area of the working elements. The active area of the vanes can be increased significantly, but should be optimized according to the many limits of design.Increase the number of frames increases the vane interframe wind shadow area and increases the weight of turbine.

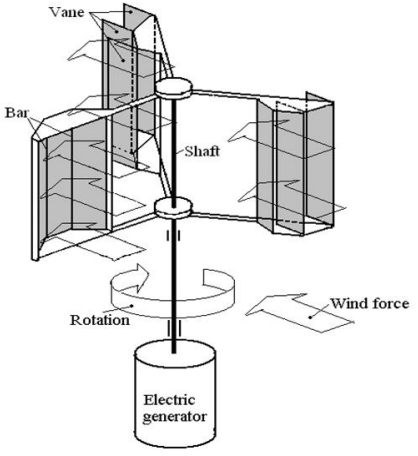

a)

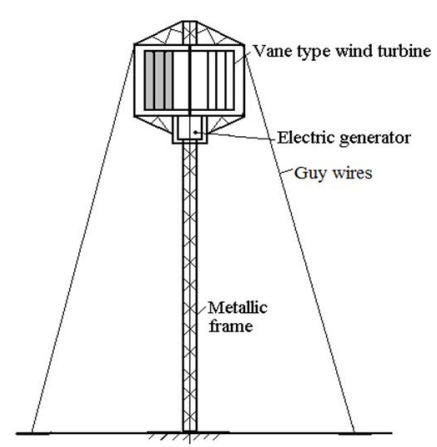

b)

Fig. 1: a) Sketch of the vane type wind turbine, b) and general view of wind station. 
The sketch of the impeller type wind turbine is presented in Fig. 1. The turbine can be designed by three, four or more frames that lead to increase the acting area of the vanes and lead to increase of the weight one. Frame is designed with movable vanes located on the vertical bars. At a left side of the turbine, under action of the wind force the vanes are rotated and create scoop shape when closed frames, which capture the wind kinetic energy with high value of the drag factor. At a right side of the shaft, the vanes are open and wind force passes through the open frame. The torque created by the wind force rotates frames with the output shaft, which transfers the torque via gearing to the electrical generator.Frame elements should be designed in aerodynamic form to reduce a drag force on the wind action for not working elements of a turbine.

This turbine typeis similar to Savonius design, which works on differences of the drag factors of left and right sides scoops. New turbine uses mainly one side drag factor that can increase dramatically the turbine's output power. Also, new wind turbine enables to use the high wind velocity by lift its construction on high altitude by the metallic frame tower (Fig. $1 b)$.

\section{ANALYTICAL APPROACH}

The theoretical maximum power efficiency of any design of wind turbine operating in open atmosphere is $C_{e}=0.59$ - the Betz Limit [1,2]. No more than $59.3 \%$ of the available power in the wind can be extracted. No turbine to date has exceeded this limit[11]. In the world the real limit is well below the Betz Limit with values of 0.35-0.45 in the best designed wind turbines. There are other energy losses in a complete wind turbine system (the generator, bearings, power transmission, etc.) and only $10 \%-30 \%$ of the power of the wind is ever actually converted into usable electricity [10].

The fluid dynamics theory gives a formula with minor variations for calculation of the power for the different wind turbine designs. The fundamental equation that governs the power output of a wind turbine is [7]:

$$
P=0.5 * \rho^{*} A^{*} V^{3} * \lambda, \operatorname{Watt}(1)
$$

where: $P$ - power produced by the wind turbine, W; $\rho$ - air density, $V$ - wind speed approaching the wind turbine, $\lambda=$ wind turbine efficiency for common case; and $A$ - projected area of the turbine perpendicular to the approaching wind.

The parameter $\lambda$ is wind turbine efficiency that consists following factors and calculated by following formula:

$$
\lambda=C_{p} * C^{*} N_{g} * N_{b}
$$

where $C_{p}$ - coefficient of performance $\left(C_{p}=0.35\right.$ for a good design); $C=C_{l}$ or $C_{d}$ (or resulting of them) - are lift and drag factors respectively which are depended on the shape and form of the blades or vanes and on orientation of the wind flow with respect to the object; $N_{g}$ - generator efficiency $(80 \%$ or possibly more for a permanent magnet generator or gridconnected induction generator); $N_{b}$ - gearbox/bearings efficiency (95\% for a good design)

It is well-known that modern wind turbine is designed with very complex optimality criteria involving more than improving aerodynamic efficiency. The main objective is to 
maximize the drag factor $C_{d}$, which is a function of the turbine element geometry, Reynolds number, and Froude number.

Determination of $C_{d}$ drag factor is the most difficult part of this procedure. It is highly variable, and many parameters can affect the final $C_{d}$. Shape, altitude, inclination to the wind direction and wind speed, surface roughness, spin, and nose bluntness are just a few that can influence $C_{d}$. Many researches dedicate to study the drag factor and results of investigations can be quite different. The drag factor can vary on $C_{d}=1.2$ to 2.1 for simple $2 \mathrm{D}$ flat plate [8, 9]. However, among the three methods for calculating $C_{d}$, which are experimental; theoretical and numerical CFD procedures, the most realistic and straight forward method for the present wind turbine blade shape is using a wind tunnel. This involves solving Eq. (1) for $C_{d}$, then placing a model in a wind tunnel ( $\rho, A$, and $V$ already known). Test results are used to measure the force acting on the device that holds the model and calculate $C_{d}=F / A$.

Mathematical modeling of the wind turbines power is a very difficult problem and generally should be solved using Computational Fluid Dynamics. Finally, results of mathematical modeling should be verified by practical tests in the aerodynamic wind tunnel. For this contribution simple mathematical descriptions of the wind turbine design and its work can give initial information and ability to evaluate the proposed construction.

In the present work two models of the scoop-vanes wind turbine are analyzed. Plan view of the vane type wind turbine are presented in Fig. 2 and 3 The first model of the vane type turbines is four sections of vanes assembled on frames, which are perpendicular to each other and joined with the main output shaft. The second one is three frames the scoop-vanes wind turbine.The model has three sections of scoop-vanes, which forms an angle of $120^{\circ}$ to each other and joined with the main output shaft.
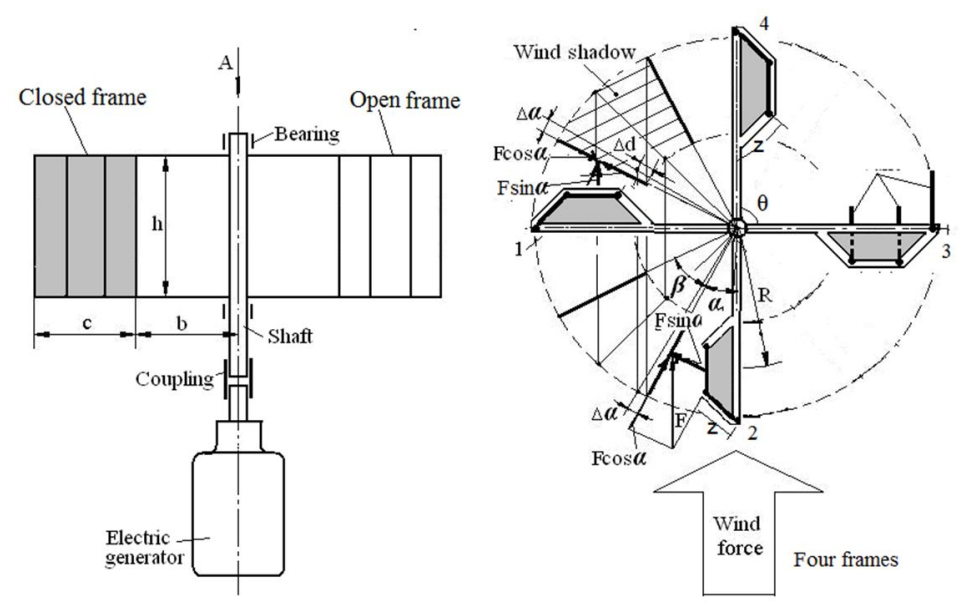

Fig. 2: Vane type wind turbine of four frames.

Power output depends on a wind force and speed and the acting surface area $A$ of vanes that located at one side of the output shaft. Relationship between acting physical parameters on the vane can be considered by known approaches. Acting forces, location of the vanes, wind shadow, and the wind pressure on the vanes is proportional to some power of the wind speed. The first thing is to calculate the force acting on the vanes due to the momentum 
change of the air impinging upon them. It is necessary for analytical approach the ultimate simplification of considering the force acting on stationary vanes.

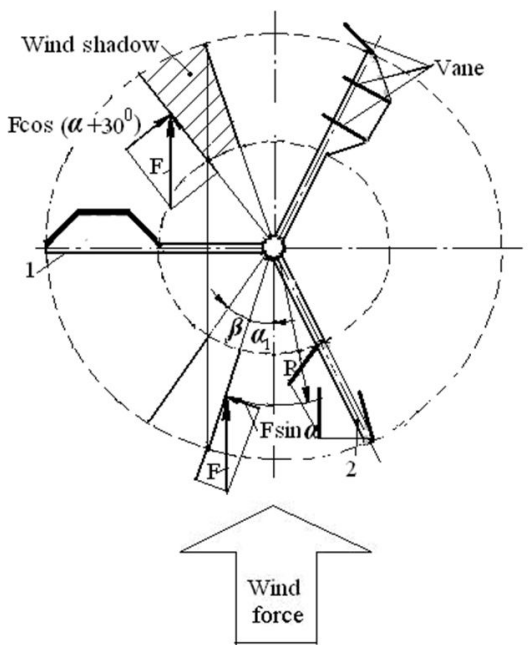

Fig. 3: Vane type wind turbine of three frames.

This simplification leads to different results depending on the assumptions made. The important assumptions are as follow:

a) The wind turbine vanes are smooth.

b)The air hitting the vanes has no viscosity. It is further assumed that air, having struck on the vanes, moves off along the surface without causing a tangential frictional force.

c) The drag force acting on the left and right frame components is equal.

Force component Facting on stationary vertical vanes of left side frame is expressed by the following formula [1-3]

$$
F=(1 / 2) C_{d} \rho A V^{2} \sin \alpha=\mathrm{p}^{*} \mathrm{~A}
$$

where pis the air pressure.

To determine the starting torque $T$ on wind turbine vanes, it is necessary to define the whole vanes area, and distance from centre of output shaft to the centre of wind pressure, then the formula has the following expression

$$
T=(1 / 2) A C_{d} \rho V^{2} R \sin \alpha
$$

where $R$ is distance from the shaft center line to the center of pressure of the vane surface, other parameters specified above.

The output power is calculated by the following equation:

$$
P=T \omega=(1 / 2) A C_{d} \rho V^{2} R \sin \alpha^{*} V / R=(1 / 2) A C_{d} \rho V^{3} \sin \alpha(\mathrm{Watt})
$$

where $\omega$ is the angular velocity of turbine rotating, other parameters specified above.

Next step is to develop the mathematical model of the resultant force acting on moving vanes. This entails determining

a) the velocity of oncoming air relative to the front surface of the first frame vanes and 
b) the affect of the wind on the surface of the second frame vanes.

In rotation of the frames with vanes, pressure builds up along the surface of an object. A surface more perpendicular to the stream line of wind tends to have a higher pressure. The resultant force acts in the center of pressure that is found by calculating the pressure distribution across of the variable vanes location, then integrating it. The forces acting on the sides of the frames can be neglected due to face sided small areas.

A good vane design will combine the aerodynamics, the mass properties, and the spin of the vane to permit the projectile to be pointy end forward for the entire airstream line. However, the vary location of the frames with vanes contributes to instability of the forces acting on the vanes and instability of the output shaft rotation.

The scoop-vane, with its plane normal to the airstream, represents a common situation for wind force loads on the vane. For a scoop-vane its plane normal to the wind flow, the only aerodynamic force will be one parallel to the wind flow, i.e. a wind force.

Practice shows, that the value of the drag factor $C_{d}$ is variable and depends on many factors like vanes configuration, wind speed, the wind angle of attack with respect to vanes, etc. There is also a tangential component or 'skin friction' force [4].

The wind turbine of three frames works variably with one and two frames that located at left side from its vertical shaft. The vanes from right side are mainly open, but some vanes are closed due to angular location and wind force acts on their surfaces (Fig. 3). The frames with vanes located $120^{\circ}$ each other due to design of the wind turbine. Location of the acting vanes is variable due to rotary motion of the turbine, so the torque created by the wind force also variable. It is very important to know the variation of the torque applied on the shaft to calculate the output power. Fig.2, 3 presents the sketch of the calculation the forces acting on the vanes that enables to calculate the torque applied to the wind turbine shaft.

The left side of the scoop-vane turbine has acting frames that create the torque due to action of the wind force. The vanes of frames work at different conditions. The second frame vanes acts after rotation of the first frame vanes on $30^{\circ}$. The wind shadow zone is also different. The first frame's vanes work with wind shadow at some angles of rotation of the second frame vanes. The second frame's vanes work without wind shadow.

Thetorque created by the first and second frames with group of vanes can be calculated by the following equations:

$$
T_{1}=C_{d} p(h c)[b+(c / 2)] \sin \alpha
$$

The power generated by the impeller type wind turbine is calculated by the equation:

$$
P=C_{d} k \lambda p \frac{V}{R} h c\left[b+\left(\frac{c}{2}\right)\right] \sin \alpha(6)
$$

where frame factor $k=1.16$ for four frame turbine; $k=0.9$ for three frame turbine; other components specified above.

\section{A WORKING EXAMPLE}


The vane type turbine has following dimensions: $c=1.0 \mathrm{~m}$-Total vane width, $b=1.0 \mathrm{~m}$, cavity shape with angle $(45)^{\circ} \mathrm{Z}=0.46$ - length of open frame part, $h=2.0 \mathrm{~m}$ - height of frame, $C_{d 1}=1.6$ - drag factor accepted conventionally for rotating vanes. $C_{d 2}=1.0-\mathrm{drag}$ factor accepted conventionally at wind shadow. The pressure acting on the vane: $p=70 \mathrm{~N}-$ wind force at condition of the wind speed $V=10 \mathrm{~m} / \mathrm{s}$. The air density $\rho=1.25 \mathrm{~kg} / \mathrm{m}^{3}$, coefficient of performance $C p=0.3$.

The maximum torque created by one frame is

$$
T_{1}=C_{d 1} p(h c)[b+(c / 2)]=1.6 * 70 * 2 * 1[1+(1 / 2)]=336 N m
$$

The power generated by the vane wind turbine is calculated by the following equation

$$
P=\left(T_{a v} V / R\right) . \lambda
$$

1. Four frames turbine $P=\left(T_{a v} V / R\right) . C_{p} \cdot N b \cdot N g=(390 * 10 / 1.5) * 0.3 * 0.8 * 0.95=592.8 \mathrm{~W}$,

2. Three frames turbine $P=\left(T_{a v} V / R\right) C_{p} . N b . N g=(302.4 * 10 / 1.5) * 0.3 * 0.8 * 0.95=459.6 \mathrm{~W}$

The power generated by the vane type wind turbine of four frames by known Eq. (1) is

$$
\begin{aligned}
P & =0.5 * \rho^{*} V^{3 *} A * \lambda, \text { Watt } \\
& =0.5 * 1.25 \mathrm{~kg} / \mathrm{m}^{3} * 10^{3} \mathrm{~m} / \mathrm{s} * 2.83 \mathrm{~m}^{2} *(0.3 * 1.6 * 0.8 * 0.95)=645 \mathrm{~W},
\end{aligned}
$$

where $A=2 * h * c^{*} \cos 45^{0}=2.83 \mathrm{~m}^{2}$ - maximum acting area of two acting vanes. There is small difference between results calculated by Eq. (7) and Eq. (1) that can be explained by approximations accepted for both approaches.

\section{RESULTS AND DISCUSSION}

Theoretical calculations of the torque for the vane type turbines conducted by Eqs. (1) and (7) shows a small different result even if except low magnitude of power. nevertheless, results shows that new type wind turbines possess better technical properties than other type turbines and can be used for generating a power. The impeller type turbine with scoop-vanes has higher efficiency compares with flat vanes. This is caused the new design wind turbine has a high drag factor, so enables to capture wind energy. This type wind turbine has good technical properties and can be used for generating a power more efficiently for the low speed of the wind.

The proposed vane turbine can be designed from cheap material that is highly economical. The work of the vane turbine does not have restrictions. At strong wind conditions, it is possible to design the vane turbine with decreased acting numbers of vanes. The possible flipping of the vanes under action of the wind force can be avoided by simple constructive solutions.

\section{CONCLUSION}

New vane type wind turbine possesses many positives properties and can solve the problem of increase wind energy use. The vane type wind turbine can be high efficiency and enables increase in the vanes acting area and drag factor that can increase the output power. 
New impeller wind turbine with movable vanes possesses all advantages of vertical and horizontal types of turbines and can be concurrent for known wind turbine designs. The new turbine presents simple construction and uses simple technology, and for manufacturing can be made from cheap materials. For future research, mathematical modeling of the wind turbine work should be conducted on a basis of Computational Fluid Dynamics and proved by practical investigations in the wind tunnel. Also, it is necessary to conduct investigations on the optimal design of new turbine (power as a function of the vanes geometry, weight of turbine, aerodynamic shape, wind speed, etc.). Tests of the vane type wind turbine in the wind tunnel and correction of the mathematical model can give reliable data in order to design of the vane type wind turbine.

\section{REFERENCES}

[1]Manwell JF, MC Gowan JG, Rogers AL. Wind Energy Explained, Theory, Design and Application. Willey\& Sons 2002;Ltd, England.

[2] Mathew S. Wind Energy Fundaments, Resource Analysis and Economics. 1st ed. Springer 2006; Vol. 1.

[3] Ackermann T. Wind Power in Power System, Willey \& Sons 2005: Royal Institute of Technology, Stockholm, Sweden.

[4] Burton T, Sharpe D, Jenkins N, Bossanyi E. Wind Energy Handbook. Willey \& Sons 2000; New York.

[5] Eggleston DM., Stoddard FS. Wind turbine engineering design. Willey \& Sons 2004.

[6] Spera DA.Wind Turbine Technology. ASME Press 1994; New York.

[7] Munson BR, Young DF.Okiishi TH.Fundamentals ofFluids Mechanics $4^{\text {th }}$ ed. 2002; John Wiley \&Sons, Inc.

[8] Mehrdad Shademan1, Horia Hangan. Wind Loading on Solar Panels at Different Inclination Angles. 11 Americas Conference on Wind Engineering - San Juan, Puerto Rico June 2009

[9] A. Fage, F.C. Johanson, On the Flow of Air behind an Inclined Flat Plate of Infinite Span, Proceedings of the Royal Society of London. 116, No. 773, (1927) 170-197.

[10] R. Usubamatov, Z.M.Zain, R. Bhuvenesh, F.Khammas. New vane type wind turbine of high efficiency, CNGRT88. Proceedings of World Engineering Congress 2010 (WEC2010), Kuching SDaravak, Malaysia, p. 418-428.

[11] Dynamic Modeling of GE 1.5 and 3.6 Wind Turbine-Generators. Miller, Nicholas, William, Price and Sanchez-Gasca, Juan. s.l. : GE Power Systems, 2003. 